\title{
City Lights and the Emergence of Beat Poetry: How Howl and Other Poems redefined Poetic and Cultural Boundaries in the mid-1950s
}

City Lights et la naissance de la poésie Beat: Comment Howl dans Other

Poems a redéfini les frontières poétiques et culturelles au milieu des années 1950 ?

City Lights y el nacimiento de la poesía beat: ¿Cómo Howl and Other Poems redefinió las fronteras poéticas y culturales a mediados de los años 50?

\section{Peggy Pacini}

\section{(2) OpenEdition}

\section{Journals}

Édition électronique

URL : https://journals.openedition.org/ideas/1992

DOI : $10.4000 /$ ideas. 1992

ISSN : 1950-5701

Éditeur

Institut des Amériques

Référence électronique

Peggy Pacini, « City Lights and the Emergence of Beat Poetry: How Howl and Other Poems redefined Poetic and Cultural Boundaries in the mid-1950s », IdeAs [En ligne], 9 | 2017, mis en ligne le 13 juillet 2017, consulté le 18 octobre 2022. URL : http://journals.openedition.org/ideas/1992 ; DOI : https:// doi.org/10.4000/ideas.1992

Ce document a été généré automatiquement le 18 octobre 2022.

\section{(i) $\odot$

Creative Commons - Attribution - Pas d'Utilisation Commerciale - Pas de Modification 4.0 International - CC BY-NC-ND 4.0

https://creativecommons.org/licenses/by-nc-nd/4.0/ 


\title{
City Lights and the Emergence of Beat Poetry: How Howl and Other Poems redefined Poetic and Cultural Boundaries in the mid-1950s
}

\author{
City Lights et la naissance de la poésie Beat: Comment Howl dans Other \\ Poems a redéfini les frontières poétiques et culturelles au milieu des années \\ 1950 ? \\ City Lights y el nacimiento de la poesía beat: ¿Cómo Howl and Other Poems \\ redefinió las fronteras poéticas y culturales a mediados de los años 50 ?
}

Peggy Pacini

\section{Introduction}

1 With about a dozen books published a year and nearly 200 books in print, City Lights Publishers has managed to gain international fame while implementing an unflinching original editorial policy and commitment. Over the years, they have pursued an independent stance and remained a small press. If the poet Lawrence Ferlinghetti has been tagged the publisher of the Beats and despite the close relationship City Lights and the Beat poets have cemented, City Lights Books is not beat-centric. Poetry and much less beat poetry only account for about $20 \%$ of the books City Lights publishes. And still the two names are so closely associated, not to say undifferentiated. That Ferlinghetti (1919-), a central figure of the San Francisco literary scene and of the San Francisco Beats, is also City Lights publisher partakes in adding to the confusion. And most importantly, City Lights has built a reputation on the publishing of one of the three founding texts of the Beat Generation, "Howl” by Allen Ginsberg (1926-1997).

2 This paper intends to consider to what extent City Lights has been instrumental in launching Beat poetry and providing in the mid-1950s a springboard for the East Coast- 
born Beat movement on the West Coast. Digging into the equation Beat poetry-City Lights is entering an intricate maze whereby each reference cannot be conceived independently but in connection with a myriad other names, places and facts of the various vibrant and renegade-spirit Bay Area poetic and artistic circles and communities. A glimpse at the West Coast cultural scene at the time might serve as a brief introduction to the literary effervescence of the Area that gave birth not only to City Lights but to the Beat Generation too.

3 In "West Coast Rhythms" an article published in the New York Times on September 2, 1956, the literary critic and poet Richard Eberhart (1904-2005) frames the pictures and asserts that "the West Coast is the liveliest spot in the country in poetry today" before listing the combinations that contributed to the emergence of "a radical group movement of young poets" (Ginsberg A., 1995: 154). Among them the establishment of the Poetry Center at San Francisco State College originated by professor Ruth WittDiamant, the mentoring presence and influence of the poet Kenneth Rexroth (1905-1982), the numerous poetry readings, all combining into "an enthusiastic, authentic, free-wheeling celebration of poetry" (Ginsberg A., 1995: 155) in jazz joints, cafés and art galleries. In the early 1950s, the West Coast literary scene was largely monopolized by the San Francisco Renaissance poets - Rexroth, Kenneth Patchen (1911-1972), Jack Spicer (1925-1965), William Everson (1912-1994) as leading figures. No single aesthetic style bound them all though - a characteristic they shared with the Beat poets. Ever since the 1950s, the Bay Area has been a constant incubator for social, cultural and political movements challenging both establishment and convention, epitomizing bohemian lifestyle, fusing popular and high culture while naturally bringing spirituality to the street.

Finding many echoes to their own philosophy and vision of art and literature in the literary communities of the West Coast, the Beats from the East Coast (essentially Jack Kerouac and Ginsberg) instinctively joined the North Beach scene as early as 1954. The movement was born in 1944 at Columbia University around Ginsberg, Kerouac (1922-1969), William S. Burroughs (1914-1997) and Lucien Carr (1925-2005). All of them were concerned with fostering a new vision that was to inform their work and technique. They rejected the modernist canon as well as most form of academism and favoured a more redeemingly pure and authentic vision of art grounded on improvisation, spontaneity, immediacy, the vernacular and jazz, and induced by drugs. In 1954, most of them were still relatively unknown and unpublished. Most will argue that the meeting of the East Coast Beats with already vibrant San Francisco artistic communities will be decisive for the movement. It was certainly a determining factor for one of them, Ginsberg, but also as a matter of consequence for all the East Coast Beats - Gregory Corso (1930-2001), Diane di Prima (1934), Leroi Jones/Amiri Baraka (1934-2014) - and even for some experimental Bay poets who got associated with the movement then and afterwards, as Gary Snyder (1930-), Michael McClure (1932-), Bob Kaufman (1925-1986), Phil Whalen (1923-2002) or Harold Norse (1916-2009)2.

5 The San Francisco Renaissance poets and Beat poets alike shared common poetic techniques and beliefs that might have been at the origin of the confusion that still prevails to this day as to what is a Beat poet, who is an insider and who is an outsider. Michael Davidson in his history of the San Francisco Renaissance seems to lay the blame on literary critics who partook in the confusion (Davidson M., 1989: 4-6). Rexroth, for instance, was already performing poetry to jazz long before Kerouac did, 
but Kerouac turned into it a writing technique aesthetics. If the literary exchanges and the fruitful collaborations arising from these mid-1950s were extremely valuable, they also fuelled the conditions for the confusion that persists to these days as to what is the Beat Generation and who is a Beat poet. In "The Origins of Joy in Poetry," Kerouac seems to make no real difference between the two and includes himself, Gregory Corso and Ginsberg in the San Francisco Renaissance (Kerouac J., 1996: 74) ${ }^{3}$. Gary Snyder, on the other hand, makes a clear distinction between the Beat Generation and the San Francisco Poetry Renaissance, which he defines as a literary and political movement, "characterized by its independence from East Coast and European poetic thinking, its independence from what we call neo-Formalism, its freedom from the problems and contradictions experienced by American intellectuals of that period" (Lauridsen and Dalgaard, 1990: 67). On the contrary, Snyder regards the Beat Generation as "an overall

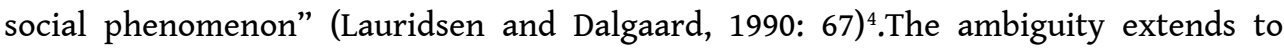
underground, experimental Bay Area poets and prose writers. In fact, the term Beat Generation has become useful to classify many unclassifiable poets who happen to share reading stages and magazine pages. Ginsberg regrets that the term has the disadvantage of putting things in a box which are outside of the box (Lauridsen and Dalgaard, 1990: 23). However, he isolates common grounds and common insight: an open form of some kind, spontaneity in writing, the breaking up of old forms in both prose and poetry, an opening up of a consciousness (Lauridsen and Dalgaard, 1990: 23-24). It is mutation of consciousness that the Beat poets represent, so McClure concludes (Lauridsen and Dalgaard, 1990: 115).

6 Yet, this paper does not aim at debating the issue but at understanding how City Lights, a San Francisco-based small press, became not only the lighthouse in the Bay for Beat and Beat-related artists and poets but also a countercultural organ of dissent channelling new poetic visions and aesthetics starting from the mid-1950s. This will thus provide an entry into the publishing conditions of experimental works at the time while setting the frame for understanding, one the one hand, the specificities of City Lights publishers and Ferlinghetti's creation of the Poet Pockets Series collection, and on the other hand, the issue of publishing Beat works in the mid-1950s. Ginsberg's seminal opus Howl and Other Poems, number 4 of the Series, will consequently operate as a means to initiate a dialogue on the mutual influence of City Lights Publishers and the Beats, and to discuss the Beats' legacy on City Lights editorial policy.

\section{The birth City Lights the Six Gallery reading: the rise of an editor and a poet}

7 A backward glance at the story of City Lights immediately discloses the different stance it wanted to adopt and the stamp it wished to leave on publishing vanguard, experimental literature in the United States at times of containment, and most particularly in that counter-cultural hive the San Francisco Bay and Los Angeles areas fostered, and how they all interacted. Indeed, ever since it was founded in 1955 City Lights committed themselves to publishing "cutting-edge fiction, poetry, memoirs, literary translations and books on vital social and political issues ${ }^{5}$."

8 Ferlinghetti had returned from Paris in 1950, and was writing poetry reviews for the San Francisco Chronicle while also writing his own poetry and sending it to a North Beach magazine called City Lights. Edited by Peter Martin, the magazine was "an attempt to 
give voice to the cultural ferment he found developing in the San Francisco Bay Area" (Cherkoswki N., 1979: 80). Quite interestingly, the foundation of City Lights bookshop by Ferlinghetti and Martin in 1953 was closely linked to the underground press as it originated from the necessity to provide funds to publish Martin's City Lights. Moreover, his desire to promote the paperback revolution in the United States would only add to the co-founders' drive. Yet, the story of the all-paperback bookstore and, even more so, of the series under scrutiny, the Pocket Poet Series, owes much to Ferlinghetti's French experience and his understanding of publishing paperback in France.

9 Located on 261 Columbus Avenue and Broadway in the North Beach section of San Francisco, City Lights takes pride in being "a landmark independent bookstore and publisher that specializes in world literature, the arts, and progressive politics ${ }^{6} . "$ Pinpointing its essence - i.e. the double label of bookstore and publisher - City Lights hammers at the independent status Ferlinghetti has constantly striven to ensure since he took the reins of the publishing house in 1955. Since then, Ferlinghetti is City Lights Bookstore, he is City Lights Publishers. His personality, trade and ideas can be traced at various levels. First, on an editorial policy that promotes "international dissent and insurgent ferment." (Ferlinghetti L., 1995: xv-xvi). Second, and in keeping with the ethos of the independent press, on his drive to discover and disseminate avant-garde and experimental poetry, "avoiding the provincial and the academic" (Ferlinghetti L., 1995: xv) and connecting writers from all around the world through cross-currents and cross-fertilization. Such an ambition was encouraged by the San Francisco cultural scene. The already established group of San Francisco Renaissance poets ${ }^{7}$ had already been paving the way for new ideas and techniques. Among them, Larry Smith puts forward:

an openness to alternatives in lifestyle and art which spawned a wide range of diversity, a spiritual awareness connecting Eastern and Western thought in a move toward personal and cultural wholeness, an embracing of Nature as lifestyle and essential rite, a view of writing and art as a means of intuitive expression and cultural dissent that accepted avant-garde, populist, and social engagement. (Stefanelli M.A., 2004: 32)

They shared some unifying characteristics, i.e., a rhetorical impulse "related to the dramatic enhancement of subjective states" (Davidson M., 1989: 36), and loss and nostalgia as thematic. Moreover, Rexroth was also very much looking to Chinese and Japanese poetry traditions. In many ways, the Beat movement grew out of the San Francisco Renaissance. Both communities would interact and collaborate to furthering the burgeoning cultural synthesis that first found an outlet in small presses and little magazines, in cafés and co-op galleries.

The Six Gallery was one of them. It was run by young artists linked to the San Francisco Art Institute, who had been mentored by the abstract-expressionist painters Clyfford Still and Mark Rothko or by newly emerging figurative painters ${ }^{8}$. The place had a tradition of hosting experimental and vanguard performances and readings. A few months earlier, the poet Robert Duncan (1919-1988) had performed his play Faust Foutu and ended the play stripping himself of his clothes ${ }^{9}$. It was to be the venue for the now legendary reading of October 7, 1955. On that day, introduced by Rexroth, who acted as master of ceremony, four young West Coast poets - Snyder, McClure, Philip Lamantia (1927-2005), Whalen - and Ginsberg, participated in what would remain in collective memory as a founding reading ${ }^{10}$. Ginsberg and Corso in "The Literary Revolution in 
America" report it as a will to "defy the system of academic poetry, official reviews, New York publishing machinery" as well as national sobriety (Ginsberg A., 1995: 165) ${ }^{11}$. It was then that an early draft of "Howl" was read. The evening was hailed as the beginning of the Beat Generation and of a new era for poetry, which "had gone beyond a point of no return" (McClure M., 1982: 13). McClure recalls the reading of "Howl" also as a rite of passage for a whole generation of poets. He claims that "a human voice and body had been hurled against the harsh wall of America and its supporting armies and navies and academies and institutions and ownership systems and power-support bases" (McClure M., 1982: 15), no one before Ginsberg had been so outspoken in poetry. At the Six Gallery Reading a declaration of independence was made against what Mcclure defines as "the gray, chill, militaristic silence, to the intellective void - to the land without poetry - to the spiritual drabness" (McClure M., 1982: 13). A generation of poets, it seems, came of age that night, empowered with a new, outspoken, liberated voice and vision in the making.

12 Ferlinghetti was in the audience. He qualified "Howl" as the articulation of the apocalyptic message the world was waiting for (Morgan and Peters, 2006: xii).On October 13, he sent Ginsberg a telegram to congratulate him:"I GREET YOU AT THE BEGINNING OF A GREAT CAREER [stop] WHEN DO I GET THE MANUSCRIPT OF "HOWL"? [stop] LAWRENCE (FERLINGHETTI) CITY LIGHTS BOOKSTORE" (Ferlinghetti and Ginsberg, 2015: 1).

From then on, these poetry readings or performances, most of them jazz-poetry reading sessions, would change the way poetry could be perceived as a tangible social form, uniting poets and audience, "releasing the energies of the audience through spoken, even shouted verse"12 (Ginsberg A., 1995: 155). It changed the way poets thought, wrote and voiced their poetry: "blowing" the natural flow of their minds in the words of Jack Kerouac, or transcribing "the natural flow of the mind," "the melody of actual thought or speech" (for Ginsberg). (Ginsberg A., 2008: 135) Kerouac defined this new American poetry in "The Origin of Joy in Poetry" and pinpointed at the discipline they practiced in their art: "Writing whatever comes into your head as it comes, poetry returned to origin, in the bardic child, truly ORAL" (Kerouac J., 1996: 74), i.e., giving back to poetry its (corp-)orality. It is perhaps this very mixture of orality and corporality that also partook in the difficulties the Beats faced in finding an outlet for their poetry.

\section{“There's no Beat Generation, just a bunch of guys trying to get published"}

14 In 2010, Rob Epstein and Jeffrey Friedman released the animated biopic based on the Howl trial movie ${ }^{13}$. In the movie, the character playing Ginsberg, James Franco is asked by an interviewer to give a definition of the Beat Generation. The answer is at the same time puzzling from a contemporary perspective and realistic if contextualized: "There's no Beat Generation, just a bunch of guys trying to get published." The poet Jerome Rothenberg ${ }^{14}$ recalls that what Ginsberg said was: "There's no Beat Generation, just a bunch of guys trying to get fucked ${ }^{15}$." The revised version stresses one of the major difficulties Beat writers, and vanguard poets of the Bay Area at large, were confronted with. Facing general refusal from the conservative publishing establishment, many ventured into founding their own small presses or underground magazines, which 
would provide for printed recognition and dissemination of their work. Consequently, as early as the 1950s, a multiplicity of independent, small press and literary magazines was burgeoning in alternative underground literary communities on the East and West Coasts alike. This was facilitated by the advent of the mimeograph which reduced both the cost of printing and copying techniques, and production time. The mimeograph revolution helped magazines and independent bookstores to develop while at the same time providing a distribution outlet, City Lights being one of them. Since its creation, City Lights Bookstore, a natural gathering place for poets to congregate, has grown into a center of intellectual activity.

15 When in the mid-1950s City Lights began its editorial activity, very few Beat poets had been published. They were undoubtedly facing significant obstacles, and their correspondence testifies to the extent of the difficulty. When they were, it was always in small literary presses or magazines such as Neurotica ${ }^{16}$, Semina ${ }^{17}$ or Yugen ${ }^{18}$, which promoted non-conventional, radical and experimental content. The Beats owed much to alternative publishing ${ }^{19}$. As to publishing poetry, the extent of their difficulties seemed to be increased ${ }^{20}$. As a matter of consequence, when Martin and Ferlinghetti started their publishing activities in the basement of the bookstore, they defended a definite editorial policy whose ambition was to create a universal stage for new ideas and aesthetic forms. Here again, Ferlinghetti's role was instrumental. A poet himself, he supported alternative poets and created for them an alternative publishing venue with the Pocket Poets Series and launched the Series with his own Pictures of the Gone World (1955) ${ }^{21}$.

Though resulting from an individual poetics, the Pocket Poets Series enact the common ideology that informs City Lights culture and partakes of the features of performance. The importance of the format and shape of the series might help understand how influential they have been in spreading the work of these poets. First, the launching of City Lights publishers corresponded to the launching of the Pocket Poets Series. Both were intimately related in serving as a forum for Beat and experimental poets but also as a new means to spread poetry to the streets. The publishing house was born around poetry. Measuring about $15,5 \times 12,5 \mathrm{~cm}$, the small format paperback certainly partook in its success and impact. And so do its recognizable shape and design - saddle-stitched by two wire staples in stiff black/red/dark blue paper wrapper printed in yellow/black/ light blue on front and rear covers with yellow/white paper wraparound label pasted on, lettered in black. The inside front and rear covers were blank, the paper was cream or white laid or wove and the number of pages averaged 12 to 40 . Its shape and size are to a certain extent a declaration of independence, their format, a "challenge to literary convention" (Stefanelli M.A., 2004: 79).

The handy format, that can be easily be slipped into the back pocket of a pair of jeans, was part of an attempt to popularize poetry, to take it out of libraries into the street. In his essay "The Trials of Manhood: Censorship, the Body and the City Lights Pocket Poets Series," Nick Selby is right advocating that the Series speaks of a poetics of portability that encouraged their readers to occupy a dissident space out in the open, to become itinerant bohemians (Stefanelli M.A., 2004: 79). In fact, the format itself resists conformity, and it speaks to a readership not confined to the office or organisation.

On the other hand, the Pocket Poets Series set the tone for an emerging, radical poetics in post-war America. At the time, Ferlinghetti's aim was already global as revealed by 
his own international perspective and his determination to extend the Beat alliances to an international avant-garde ${ }^{22}$.

One specific number of the Pocket Poets Series though deserves closer attention: Pocket Poets Series number four, i.e., Allen Ginsberg's Howl and Other Poems. If Ginsberg's opus remains to these days City Lights Publishers' bestselling title, it should be underscored that in the mid-1950s no mainstream publisher wanted to publish it. No wonder then that it became a catalyst in a paradigm shift in American poetry and consciousness. A backward glance at the history of the publication of "Howl" shows that it did comply with City Lights editorial policy, but it also stood as a landmark altogether in the field of poetry and publishing.

On the title page, the black lettering title (HOWL AND OTHER POEMS), and author name stand out on the creamy background; below, a peritext serves as the author's poetic manifesto: "Unscrew the locks from the doors! / Unscrew the doors themselves from their jambs!" Beside vouching Ginsberg's filiation to the Bard, these two lines from Whitman's "Song of Myself" set the prevailing tone of the poem. The booklet comes with an introduction by William Carlos Williams. The 22-leave cream woven opus contains eleven poems by Ginsberg ${ }^{23}$. The title of Williams's introduction "Howl for Carl Solomon" is indeed Ginsberg's original title for his opus. Solomon was a writer Ginsberg had met when he was cured at Grey Stone Park mental institute. Yet, intent on preserving an editorial policy that advocated a global cultural spirit, Ferlinghetti asked Ginsberg to give the title a more universal turn, and seeing madness as a collective disease resulting from the global social and political tensions, thus keeping simply "Howl" for the title and turning "for Carl Solomon" into a dedication.

21 First published on October 1956 at 75 cents, the first 1500 copies printed by Villiers Publications in London sold quickly. 520 of the 3000 second printing copies were seized by Chester McPhee, the federal collector of Customs for the $18^{\text {th }}$ district of San Francisco, on the ground of obscenity on March 25, 1957, then released two months later by the U.S. Customs Office in San Francisco. However, in June 1957, the local police raided City Lights Bookstore and Ferlinghetti was arrested with Shigeyoshi Muroa (the store's manager). The trial (The People of the State of California vs. Lawrence Ferlinghetti) lasted the whole summer.

\section{6: "Howl" on trial, redefining the contours of post- war American poetry on the ground of obscenity}

The history of the Howl seizure addressed a major issue which became City Lights' lifelong hobby-horse. Ferlinghetti spots at least two reasons for its seizure. Firstly, its content and target: the poem attacked "the bare roots of our dominant culture, the very Moloch heart of our consumer society" (Morgan and Peters, 2006: xi). Secondly, its countercultural stance: the seizure was part of the government's [McCarthy's] tactics in persecuting the underground, counter-culture press and forcing it to go bankrupt and this by involving them in costly legal proceedings (Zott L.M., 2003: 314). The case more than the book perhaps had immense aftermaths on the publishing world at the time. It was City Lights' first long-term fight against prejudice. Chester McPhee banned "Howl" on the ground that "the words and the sense of the writing is obscene. You wouldn't want your children to come across it," to which Ferlinghetti reacted declaring:"it is not the poet but what he observes that is revealed as obscene ${ }^{24}$."Having anticipated the 
censorship problems and the knock-on effect this would have, Ferlinghetti had submitted beforehand a copy of Howl and Other Poems to the American Civil Liberties Union. Ferlinghetti admits that the times required him and the publishing world to take a stand on the question of censorship. As such, one may wonder whether publishing Howl was not a deliberate act of civil disobedience, of literary and political dissent. The massive support Ferlinghetti did receive from editors, poets (Denise Levertov among them), educators, and critics proved that they somehow welcomed, perhaps even, were waiting for this rebirth and adaptation of a Whitmanian call when times were at a certain conformism and uniformity ${ }^{25}$.

How far the case and the international attention it received impacted the life and career of Lawrence Ferlinghetti, the whole San Francisco Renaissance and the West Coast Beat Movement is difficult to measure. This dispute over the charges of obscenity marked a turning point in post-war America attitude to sex and censorship. "Howl" was testing and exploring the limits and the rhetoric of America's post-war containment culture through a catalogue of "evils of [the] time from physical depravation to madness" (Miles B. in Ginsberg A., 1986: 155). But, quite interestingly, it was equally the content the form, and the materiality of the booklet that were censored: its raw, unmediated language and its explicit references to sex, homosexuality and drugs. Conformity and containment indeed were challenged as the text always negotiates and crosses the limits and excesses of the policed body - a site reformulating the repressive boundaries of the Cold War culture and eluding the censorship as the "howl" barbarically takes over.

On a national and international scale, Ferlinghetti and Ginsberg helped bring about a revolution in thinking as well as writing. Not only did the case politically challenge the issue of censorship, it also allowed a brewing poetic vision, form and style to be voiced and it brought poetry to the foreground as a public matter (Stefanelli M.A., 2004: 63). In "The Literary Revolution in America," Ginsberg and Corso wrote that the reading of "Howl" at the Six Gallery "restored to American poetry the prophetic consciousness [it] had lost since the conclusion of Hart Crane's The Bridge" (Ginsberg A., 1995: 165).

Suffice it to read Ginsberg's letter to Eberhart dated May 18, 1956 to grasp the poetic manifesto the volume contained (Ginsberg A., 2008: 130-139) ${ }^{26}$. Written prior to Eberhart's article "West Coast Rhythms," the letter not only offers a detailed analysis and presentation of the volume, listing its values and techniques, it also gives a brief outlook of the poetry situation in San Francisco. It largely anticipates the objections and misreading the volume and eponymous poem would be charged with. Clearly refusing to conform to "the artificial preoccupations and preconceptions of what is acceptable and normal" (Ginsberg A., 2008: 131). The poem and Ginsberg's method aims at releasing, confessing and communicating true feelings. At the same time, it claims poetry's liberating effects on both self and audience. Like Whitman, Ginsberg's stance is to "speak the password primeval" and "give the sign of democracy ${ }^{27}$." Ginsberg suggests that Howl partially solved the breakthrough begun by Whitman but never carried forward: using the long line to free speech for emotional expression while also giving it a measure to work with (Ginsberg A., 2008: 139). Ginsberg reads the technical composition of "Howl" as a metrical liberation, which the three parts exemplify: building up consecutive rhythm from strophe to strophe (using mostly a fixed base), breaking it up within the strophe so as to use it as a new form of stanza, measuring by 
ear and speech breath each set of phrases strophe."Howl" is Ginsberg's technical experiment, which he will later transform and adapt to shorter forms.

The poem as it was delivered at the Six Gallery and then disseminated and censored stands as a stepping stone in American poetry at thematic and compositional levels. A landmark for free speech, the case established the legal precedent that a book with a "redeeming social significance" (Morgan and Peters, 2006: 197) ${ }^{28}$ could not be attacked of obscenity, while allowing other presses to publish banned books elsewhere.

\section{Conclusion}

If as mentioned in the introduction, Beat poetry only accounts for $20 \%$ of the books City Lights publishes today, what has helped City Lights gain their trademark (i.e., the Pocket Poets Series, the Howl trial, publishing dissident, subversive works) seems to prevail to these days. The Beats' legacy of anti-authoritarian politics and insurgent thinking, here exemplified by Ginsberg's poem, continues to be a strong influence in the store, and browsing at the selection of titles testifies that the Beat centric association of the place and institution is still relevant today. Though there seems to be no agreement as to the real influence of Ferlinghetti's Pocket Poets Series on the Beat Movement or of Ginsberg's "Howl" on the existence of City Lights, the success of City Lights is connected to the declamation of Howl. Yet, Ferlinghetti himself rejects some of the Beats' influence, especially Ginsberg's: “Ginsberg didn't have very much influence on what we published, because I've never published across the board. We've never wanted to be known as exclusively the publisher of the Beat poets. I didn't publish the Beat poets across the board" (Zott L.M., 2003:317). However, as Stefanelli recalls, in her introduction to her volume on the Pocket Poets Series, the publication of many of the Beat-labelled poets alongside the commitment to the politics of dissent and the intellectual participation in innovative aesthetic tradition provided the background for the framework of engagement (Stefanelli M.A., 2004:8). Moreover, the letters between Ginsberg and Ferlinghetti also testify to their mutual influence in disseminating and publishing Beat poetry (Ferlinghetti and Ginsberg, 2015).

If the Pocket Poet Series was instrumental in bringing poetry to the street it is also because the poets published in the Series took from the street the marrow of their art. If the Beats helped popularize poetry it is in its noblest sense by redefining the figure of poetry and of the poet in society.

29 It also set the frame for what can be seen as a global beat poetry community whose individualities collaborate, influence and nourish one another. Moreover, by bringing forth the elements that have presided over this intimate relationship, this paper acknowledges both City Light Publishers' role in earning the Beat poets some recognition, starting with Ginsberg, and the influence of Beat works on City Light's fifty years' existence and reputation. Eventually, it also hinted to the fact that the combination in place and time, and over the years helped redefine cultural and poetic boundaries while partaking in creating two paradoxes: the first mainstream independent small press and the first mainstream countercultural literary movement. 


\section{BIBLIOGRAPHIE}

Campbell, James, This is the Beat Generation: New York, San Francisco, Paris, London, Vintage, 2000.

Cherkowski, Neeli, Ferlinghetti, a Biography, New York, Doubleday, 1979.

Corso, Gregory, The Vestal Lady on the Brattle and Other Poems, Cambridge, Richard Brukenfeld, 1955, San Francisco, City Lights Books, 1969.

Corso, Gregory, Gasoline, Pocket Poet Series 8, San Francisco, City Lights Books, 1958.

Dana, Robert (ed.), Against the Grain: Interviews with Maverick American publishers, Iowa City, University of Iowa press, 2009.

Davidson, Michael, The San Francisco Renaissance: Poetics and Community at Mid-Century, New York, Cambridge University Press, 1989.

Duncan, Robert, Faust Foutu: a comic masque, Barrytown, Station Hill Press, 1985.

Eberhart, Richard, “West Coast Rhythms," New York Times, September 2, 1956, p. BR4. reprinted in Allen Ginsberg, Howl. Original Draft Facsimile \& Variant Versions, Fully Annotated by Author, with Contemporaneous Correspondence, Account of First Public Reading, Legal Skirmishes, Precursor Texts \& Bibliography, Barry Miles (ed.), New York, Harper Perennial, 1995, p.154-155.

Epstein, Rob and Jeffrey Friedman, (dirs.), Howl, Elizabeth Red leaf, Christine Kunewa Walker, Rob Epstein and Jeffrey Friedman, producers, Oscilloscope Laboratories, 2010.

Ferlinghetti, Lawrence, Pictures f the Gone World, San Francisco, City Lights Books, 1955.

Ferlinghetti, Lawrence, City Lights Pocket Poets Anthology, San Francisco, City Lights Publishers, 1995.

Ferlinghetti, Lawrence and Allen Ginsberg, I Greet You at the Beginning of a Great Career: The Selected Correspondence of Lawrence Ferlinghetti and Allen Ginsberg, 1955-1997, Bill Morgan (ed.), San Francisco, City Lights Publishers, 2015.

Ginsberg Allen, The Letters of Allen Ginsberg, Bill Morgan (ed.), New York, Da Capo Press, 2008. Ginsberg, Allen, Howl and Other Poems, Pocket Poet Series 4, San Francisco, City Lights Books, 1956.

Ginsberg, Allen, Howl. Original Draft Facsimile \& Variant Versions, Fully Annotated by Author, with Contemporaneous Correspondence, Account of First Public Reading, Legal Skirmishes, Precursor Texts \& Bibliography, Barry Miles (ed.), New York, Haper Perennial, 1995.

Ginsberg Allen and Gregory Corso, “The Literary Revolution in America," Litterair Paspoort 100, Amsterdam (November 1957), reprinted in Allen Ginsberg, Howl. Original Draft Facsimile \& Variant Versions, Fully Annotated by Author, with Contemporaneous Correspondence, Account of First Public Reading, Legal Skirmishes, Precursor Texts \& Bibliography, Barry Miles (ed.), New York, Haper Perennial, 1995, p. 165-166.

Jouffroy, Alain, Declaration d'Indépendance, City Lights Books, San Francisco, 1961.

Kerouac, Jack, "The Origins of Joy in Poetry," in Scattered Poems, Pocket Poet Series 28, San Francisco, City Lights Books, 1970; reprinted in Good Blonde and Others, San Francisco, Grey Fox Press, 1996. 
Kerouac, Jack, Mexico City Blues, Grove Press, 1959.

Kerouac, Jack, Scattered Poems, Pocket Poet Series 28, San Francisco, City Lights Books, 1971.

Lamantia, Philip, Tau and John Hoffman Journey to the End, Pocket Poets Series 58, San

Francisco, City Lights Publishers, 2008.

Lauridsen, Inger Thorup and Per Dalgaard (eds.),The Beat Generation and the Russian New Wave, Ann Arbord, Ardis Publishers, 1990.

McClure, Michael, Scratching the Beat Surface, San Francisco, North Point, 1982.

Morgan, Bill and Nancy J. Peters, eds. Howl on Trial: the battle for free expression, San Francisco, City Lights Books, 2006.

Rothenberg, Jerome (trans.), New Young German Poets, Pocket Poets Series 11, San Francisco, City Lights Books, 1959.

Selby, Nick, "The Trials of Manhood: Censorship, the Body and the City Lights Pocket Poets Series," in City Lights Pocket Poets and Pocket Books, Maria Anita Stefanelli (ed.), Roma, Ila Palma, 2004, p.73-91.

Smith, Larry, "The San Francisco Renaissance in Poetry and City Lights Books," inCity Lights Pocket Poets, Maria Anita Stefanelli (ed.), Roma, Ila Palma, 2004, p. 31-32.

Solnit, Rebecca, "Culture and Counter-culture: San Francisco's Fifties" in Secret Exhibition: Six California Artists of the Cold War Era, San Francisco, City Lights Books, 1990, p. 26-56.

Reproduced in Beat Generation Gale Critical Companion, Lynn M. Zott (ed.), vol. 1, Thomson Gale, 2003, p. 435-450.

Stefanelli, Maria Anita (ed.), City Lights Pocket Poets and Pocket Books, Roma, Ila Palma, 2004

Whitman, Walt, Leaves of Grass, Norton Critical Edition, New York, Norton, 1973.

Zott, Lynn M. (ed.), Beat Generation Gale Critical Companion, vol. 1, Thomson Gale, 2003.

\section{NOTES}

1. The article was reprinted in Ginsberg A., Howl. Original Draft Facsimile \& Variant Versions, Fully Annotated by Author, with Contemporaneous Correspondence, Account of First Public Reading, Legal Skirmishes, Precursor Texts \& Bibliography, Miles B. (ed.), New York, Haper Perennial, 1995, p.154-155.

2. Most of them will be published in the Pocket Poet Series (PPS).

3. Jack Kerouac, "The Origins of Joy in Poetry," first published in Chicago Review (Spring 1958) is reproduced in Scattered Poems, Pocket Poet Series 28, San Francisco, City Lights Books, 1970; and in Good Blonde and Others, San Francisco, Grey Fox, 1996, p. 74.

4. This and the preceding quotation are from an interview of Gary Snyder reprinted in The Beat Generation and the Russian New Wave.

5. City Lights' policy is advocated on thebookstore's home page http://www.citylights.com/ (accessed April 24, 2017).

6. Ibid.(accessed December 27, 2010).

7. For a history of the San Francisco Renaissance see Michael Davidson's The San Francisco Renaissance. Poetics and Community at Mid-Century (New York, Cambridge University Press, 1989).

8. It is to be remembered that the Six Gallery re-opened what a locale previously known as the King Ubu Gallery. The gallery was co-founded by Duncan, Jess Collins and Harry Jacobus and 
operated from December 1952 to January 1954. The Six Gallery followed in the political and ethical artistic path of King Ubu Gallery, giving a space for lesser-known artists to exhibit their work and hosting and staging readings and cultural events.

For a more detailed entry into King Ubu Gallery and the Six Gallery read Rebecca Solnit's essay "Culture and Counter-culture: San Francisco's Fifties" in Secret Exhibition: Six California Artists of the Cold War Era (San Francisco, City Lights Books, 1990, p. 26-56)

9. Strangely enough, the audacious action, probably one of the first daring public act by a contemporary American poet, has been forgotten by many critics.

10. Lamantia recited a few prose poems of the recently deceased poet John Hoffman, Snyder read his nature poem "A berry Feast", Whalen read his poem "Plus Ça Change..." and McClure read several poems - his Artaud inspired poem "Point Lobos: Animism," "Night Words: The Ravishing," "Poem" and his famous "For the Death of 100 Whales".

City Lights published in 2008 in the Pocket Poets Series $\left(n^{\circ} 59\right)$ a volume combining Tau by Philip Lamantia and Journey to the End by John Hoffman.

11. Allen Ginsberg and Gregory Corso, "The Literary Revolution in America," Litterair Paspoort 100, Amsterdam (November 1957), reprinted in Allen Ginsberg, Howl. Original Draft Facsimile \& Variant Versions, p.165.

12. Richard Eberhart, "West Coast Rhythms" (New York Times Book Review, September 2, 1956) reprinted in Allen Ginsberg, Howl. Original Draft Facsimile \& Variant Versions, Fully Annotated by Author, with Contemporaneous Correspondence, Account of First Public Reading, Legal Skirmishes, Precursor Texts \& Bibliography, p.155.

13. Howl, Rob Epstein and Jeffrey Friedman, dirs. Elizabeth Redleaf, Christine Kunewa Walker, Rob Epstein and Jeffrey Friedman,producers (Oscilloscope Laboratories, 2010).

14. Jerome Rothenberg translated German poets in New Young German Poets (Pocket Poets Series 11, 1959).

15. Rothenberg corrected the statement at the Conference "Poets and Publishers: Circulating Avant-Garde Poetry (1945-2010)" that was held in Le Mans, France in October 2010.

16. In This is the Beat Generation: New York-San Francisco-Paris, James Campbell specifies that Neurotica, owned and edited by Jay Landesman, was, in the late 1940s and early 50s, "the closest there was to a beat magazine" (Campbell J., 2000: 93). It is in the Spring 1950 issue of Neurotica that Ginsberg published "Song: Fie My Fum" poem - his first contribution to a magazine with a nationwide circulation (Campbell J., 2000: 95).

17. Semina was published by the assemblage artist Wallace Berman, and first issue was released in 1955. The magazine was disseminating Berman's idea of multimedia community and was an assemblage of poetry, prose, photographs and drawings.

18. As the Beat Generation Gale Critical Companion underlines "for many writers of the Beat era, publication in magazines such as Robert Creeley's Black Mountain Review, Gilbert Sorrentino's Neon magazine, or LeRoi Jones's Yugen was the first appearance of their work in print" (Zott L.M., 2003: 261).

19. The major small presses devoted to publishing works by Beat writers were City Lights, Barnett Rossett's Grove Press, and New Directions (started by James Laughlin).

20. Gregory Corso's The Vestal Lady on Brattle and Other Poems was published in 1955, Gasoline in 1958 as City Lights Poets Series n 8 ; Kerouac's Mexico City Blues was published in 1959 by Grove Press and his Scattered Poems, posthumously, in 1971 as Pocket Poets Series n 28.

21. The following two numbers were hosting Rexroth's translation of Thirty Spanish Poems of Love and Exile (Pocket Poets series 2) and the poetry of San Francisco Renaissance poet Kenneth Patchen, Poems of Humor and Protest (Pocket Poets Series 3). This was in keeping with its national and international-oriented editorial policy.

22. In 1961, Ferlinghetti published French poet Alain Jouffroy's Declaration d'Indépendance, in French as an out-of-series Pocket Poets. Among the international poets the Series published are 
the Chilean Nicanor Parra (PPS 12), the Russian Yevgeni Yevtuschenko (PPS 16) and Andrei Voznesensky (PPS 29), and more recently the Nicaraguan Ernesto Cardenal (PPS 43) or the Italian Antonio Porta (PPS 44).For the relationship between the Beat poets and the Russian avant-garde see The Beat Generation and the Russian New Wave.

23. These were: "Howl," "Footnotes to Howl," "A Supermarket in California," "Transcription of Organ Music," "Sunflower Sutra," "America," "In the Baggage Room at Greyhound," "An Asphodel," "Song," "Wild Orphan," and "In Back of the Real."

24. Part of the transcript of the trial is reproduced in Morgan and Peters, 2006: 125-199.

25. Rexroth and Mark Schorer, professor at UC Berkeley, were part of Ferlinghetti's defense at the Howl trial: The People of the State of California vs. Lawrence Ferlinghetti.

26. The 10-page letter is published in The Letters of Allen Ginsberg (Ginsberg A., 2008: 130-139).

27. Walt Whitman, "Song of Myself,' section 24, Leaves of Grass, (1973: 52).

28. Read the excerpts from the decision by Judge Clayton W. Horn (Morgan and Peters, 2006: 197-199) acknowledging that "Howl is [not] without redeeming social significance" and stating: "if the material has the slightest redeeming social importance it is not obscene because it is protected by the First and Fourteenth Amendments of the US Constitutionand the California Constitution" (Morgan and Peters, 2006: 199).

\section{RÉSUMÉS}

Cet article s'intéresse à la façon dont City Lights, une petite maison d'édition de la Côte Ouest des États-Unis, est devenue non seulement un repère culturel et éditorial pour toute une génération de poètes et d'artistes, que ce soit la Beat Generation ou les poètes contemporains de la Cote Ouest, mais aussi un organe de la contreculture, qui à partir du milieu des années 1950 a été une des courroies de transmission d'une nouvelle vision poétique et esthétique dissidente et expérimentale. Une contextualisation des conditions de publication de ses poètes à l'époque servira de cadre pour comprendre, d'une part, les caractéristiques de City Lights Publishers et la création de la série Pocket Poets, et d'autre part, la question de publication des poètes Beat. L'article se focalisera principalement sur le numéro 4 de cette série Howl and Other Poems d'Allen Ginsberg dont la censure redistribuera les cartes de la poésie contemporaine américaine. Ce qui permettra, par le truchement de Ginsberg et de son volume, de lancer un débat sur l'influence mutuelle de City Lights Publishers et des Beats ainsi que sur l'influence des Beats sur la politique éditoriale de City Lights.

This paper examines how City Lights, a San Francisco-based small press, became not only the lighthouse in the Bay for Beat and Beat-related artists and poets but also a countercultural organ of dissent channelling new poetic visions and aesthetics starting from the mid-1950s. By providing an entry into the publishing conditions of experimental works at the time, it sets the frame for understanding, on the one hand, the specificities of City Lights publishers and Ferlinghetti's creation of the Poet Pockets Series collection, and on the other hand, the issue of publishing Beat works in the mid-1950s. Ginsberg's seminal opus Howl and Other Poems, number 4 of the Series, will operate as a means to initiate a dialogue on the mutual influence of City Lights Publishers and the Beats, and to discuss the Beats' legacy on City Lights editorial policy. 
Este artículo se interesa por la manera cómo City Lights, pequeña editorial de la Costa Oeste de Estados Unidos, se transformó no solo en una referencia cultural y editorial para toda una generación de poetas y de artistas, ya sea la Beat Generation o los poetas contemporáneos de la Costa Oeste, sino también en un órgano de contracultura que, a partir de mediados de los 50 , fue una de las correas de transmisión de una nueva visión poética y estética disidente y experimental. Una contextualización de las condiciones de publicación de sus poetas en aquel entonces servirá de marco para entender, por una parte, las características de City Lights Publishers y la creación de la serie Pocket Poets y, por otra parte, la cuestión de la publicación de los poetas Beat. El artículo se focalizará sobre todo en el número 4 de dicha serie Howl and Other Poems de Allen Ginsberg, cuya censura volverá a barajar los objetivos de la poesía contemporánea americana. Ello permitirá, gracias a Ginsberg y a su volumen, entablar un debate sobre la influencia mutua de City Lights Publishers y de los Beats así como sobre la influencia de los Beats sobre la política editorial de City Lights.

\section{INDEX}

Mots-clés : City Lights Publisher, Lawrence Ferlinghetti, Allen Ginsberg, Beat Generation, petite maison d'édition

Palabras claves : City Lights Publisher, Lawrence Ferlinghetti, Allen Ginsberg, Beat Generation, pequeña éditorial

Keywords : City Lights Publisher, Lawrence Ferlinghetti, Allen Ginsberg, Beat Generation, small press

\section{AUTEUR}

\section{PEGGY PACINI}

Peggy Pacini is Associate Professor at the University of Cergy-Pontoise. Her interests in scholarship include Beat and post-Beat studies, ethnic American literature, bilingualism and translation, cultural production and communal identity. Her recent publications include "Franco-American Writers: In-visible Authors in the Global Literary Market," Race, Ethnicity and Publishing in America (2014), "Satori in Paris: Deconstructing French connection or the Legend's Satori" (2013) and « Visions of Tangier: Kerouac's Oriental Experience in Liminality » (2016). 